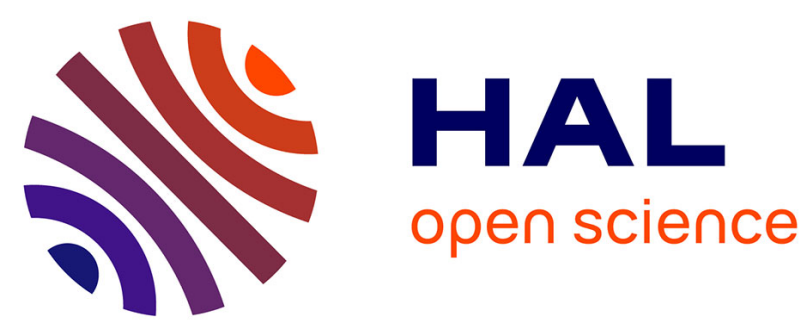

\title{
Micro Processes and Isomorphic Adaptation: Insights from the Struggle for the Soul of Economics at the University of the Holy Spirit
}

\author{
Hamid Bouchikhi, John R. Kimberly
}

\section{> To cite this version:}

Hamid Bouchikhi, John R. Kimberly. Micro Processes and Isomorphic Adaptation: Insights from the Struggle for the Soul of Economics at the University of the Holy Spirit. 2014. hal-00993435

\section{HAL Id: hal-00993435 \\ https://essec.hal.science/hal-00993435}

Preprint submitted on 20 May 2014

HAL is a multi-disciplinary open access archive for the deposit and dissemination of scientific research documents, whether they are published or not. The documents may come from teaching and research institutions in France or abroad, or from public or private research centers.
L'archive ouverte pluridisciplinaire HAL, est destinée au dépôt et à la diffusion de documents scientifiques de niveau recherche, publiés ou non, émanant des établissements d'enseignement et de recherche français ou étrangers, des laboratoires publics ou privés. 
Micro Processes and Isomorphic Adaptation: Insights from the Struggle for the Soul of Economics at the University of the Holy Spirit

\author{
Research Center \\ ESSEC Working Paper 1409
}

2014

Hamid Bouchikhi

John R. Kimberly 
Micro Processes and Isomorphic Adaptation:

Insights from the Struggle for the Soul of Economics at the University of the Holy Spirit

Hamid Bouchikhi ESSEC

Bouchikhi@essec.edu
John R. Kimberly The Wharton School University of Pennsylvania

Kimberly@wharton.upenn.edu 


\section{Abstract}

As of July 1, 2010, the College of Humanities and Social Sciences at the University of the Holy Spirit (UHS) has a single Department of Economics. However, in the seven prior years, there were two economics departments, one that was resolutely mainstream and the other that was just as resolutely heterodox. What accounts for this unusual organizational arrangement?

We show that this arrangement was part of a protracted conflict about the kind of economics that befits the Catholic identity of UHS that resulted, ultimately, in a full embrace of mainstream economics in July 2010. We draw on and amend Oliver's (1991) typology of organizational responses to institutional processes and investigate why and how UHS went from deliberate avoidance to full acquiescence to mainstream economics. Our analysis suggests that while organizations may be compelled to adapt to dominant norms, as institutional theorists contend, the process of adaptation involves a variety of conflicting moves and counter moves that engage identity and power and that require forceful leadership to resolve. 


\section{Introduction}

Between 2003 and 2010, the College of Humanities and Social Sciences (CHSS) at the University of the Holy Spirit (UHS), a Catholic institution of higher education, had two fiercely antagonistic departments of economics, a 'Department of Economics and Policy Studies', claiming a 'heterodox' identity, and a 'Department of Economics and Econometrics' which defined itself as neoclassical. Prior to 2003, there had been a single Department of Economics in the College, a department whose identity was clearly and unambiguously heterodox. Effective July 1 2010, the 'heterodox' department was closed and the neoclassical unit was renamed as the Department of Economics.

On the surface, this change may seem unremarkable. After all, from the late 1960's forward, the neoclassical paradigm became increasingly dominant in economics and mathematical modelling became the standard way of doing research publishable in the leading journals of the discipline(Lawson, 2013; Seligman, 1962). So what is noteworthy about this shift from heterodox to mainstream economics in CHSS at UHS?As it turns out, July 1, 2010 was but one moment in a long internal dispute regarding the type of economics research needed to lift the university in national rankings while, at the same time, maintaining its Catholic identity and mission to help nurture and spread Catholic Social Teachings (CST). Our longitudinal, field-based study of how the university aligned economics in the CHSS with the mainstream, an example of isomorphic adaptation, was designed to explore the nature of this dispute and to investigate how processes and behaviors at the micro level shaped outcomes at the macro organizational level. While isomorphic adaptation is at the core of institutional theory, one problem with this theoretical perspective, as Powell and Colyvas(2008)suggest, is that:

The bulk of institutional research has focused on the sectoral, field, or global level...In our view these macro-lines of analysis could also profit from a micro-motor. Such a motor would involve theories that attend to enaction, interpretation, translation, and meaning. Institutions are sustained, altered, and extinguished as they are enacted by individuals in concrete social situation.

The research we report in this paper begins to deal with that problem by identifying and analyzing the micromotors, those behaviors that were enacted by the principals in the drama and that shaped the adaptation 
process. As our research proceeded, what we found remarkable is that alignment with the mainstream took so long, unfolding over a period of more than three decades. Digging deeper, we found that the process was characterized by many failed attempts to motivate change, intensive identity work at multiple levels, and bitter conflicts involving numerous internal and external stakeholders. What on the surface seemed unremarkable turned out, on further investigation to be both fascinating and theoretically rich in its implications.

The paper is organized in three sections. In Section I, we introduce the research setting and our research process. In Section II we analyze UHS's encounter with mainstream economics and identify five phases in its painstaking and complex transition to alignment with it. We use a typology of organizational responses to institutional processes first posited by Oliver(Oliver, 1991) as a starting point and show how UHS' response to mainstream economics went from deliberate avoidance (Phase I) to paralysis (Phase II) followed by failed attempts at an evolutionary compromise between heterodox and mainstream economics (Phase III) leading to a schismatic compromise with two competing departments (Phase IV) and eventually to full acquiescence to the mainstream and termination of the heterodox department (Phase V).

In the final section, we discuss the implications of our research for understanding the micro processes of isomorphic adaptation,

\section{Empirical context and data collection}

\section{The University of the Holy Spirit}

A leading private Catholic University, UHS was founded in the $19^{\text {th }}$ century by a Congregation of the Sacred Heart (CSH) priest. The university's Catholic identity is embedded in its by-laws, governance structure, campus life, and physical plant. In many respects, UHS resembles the ideal-type of the Catholic university articulated by Pope John Paul II in the Apostolic Constitution on Catholic universities (1990). In the case of UHS, the President must be a CSH priest appointed by the Board of Trustees and assigned to that role by the Congregation. 
The tenure of individual Presidents at UHS has been remarkably long. The current President is only the third to hold the job over the last six decades. His immediate predecessor presided over UHS for 18 years and succeeded a legendary figure whose presidency spanned more than three decades. The tenure of its presidents and the continuity afforded by its affiliation with the CSH congregation have endowed UHS with a distinctive and enduring organizational identity(Albert \& Whetten, 1985). While UHS welcomes faculty and students from all faiths, or none, the university is deliberate about its Catholic character and actively seeks to attract Catholic faculty and students.

Until the establishment of the Science College in 1865, the College of Humanities and Social Sciences (CHSS) was the only college at UHS and it has, to this day, enjoyed a special status within UHS given its involvement in disciplines at the core of the university's identity such as theology, philosophy, literature, languages, and other branches of the humanities. The modern social sciences such as economics, sociology, political science, and psychology, although located organizationally in the CHSS, are politically on the periphery.

In the first century of its existence, UHS was best known for its emphasis on undergraduate teaching. According to a UHS historian, the beginning of awareness of university leaders about the importance of research goes back to the Second World War. At that time, faculty in the departments of physics and chemistry received substantial grants, by UHS standards, for participation in war related research efforts, including the Manhattan Project at Los Alamos. And in 1944, the President himself received an invitation to participate in the committee, formed at the request of the Roosevelt administration and led by Vannevar Bush, charged to study the relationships between basic research undertaken in universities and the future of American industrial development. The Bush committee authored the famous "Science, the Endless Frontier" report which paved the way for the creation of the National Science Foundation in 1950.

From his participation in the Bush committee, the President concluded that UHS could not continue to be the leading Catholic university in the post-war era unless it put more emphasis on research and graduate education. His death in 1947 did not afford him enough time to fully develop and implement a vision for UHS 
as a research university. That challenge had to be taken up by his successors and had profound consequences for the structuration of economics at UHS.

Emphasis on research grew under the leadership of his immediate successor who presided over UHS for a record 35 years. The first systematic plan to develop UHS beyond a good undergraduate college was produced in 1973 by the "Committee on University Priorities" appointed by the President.

The charge to this committee is best expressed in the broadest terms: to study the present and, especially, the future of UHS in an effort to determine what are the most important and indispensable elements of our total mission, the most essential as contrasted with that which might have seemed desirable under other circumstances. We cannot have the best of all worlds, but we must plan on principle to achieve what is best for us in our present world, what we can do superbly and what will in the foreseeable future likely be a mediocre or second-rate performance on our part, for a variety of reasons (CUP, 1973).

The Committee made a thorough review of the university and submitted a 24 page, single spaced, report containing far reaching recommendations about the Catholic character of UHS, financing, student enrollment, residence requirements, academic disciplines, teaching and research, and advanced studies. With regard to the latter area, the committee recommended:

That within the next five years, every unit in Advanced Studies should do a self-study, according to a schedule set up by the vice president for Advanced Studies. This will be followed by a thorough review performed by an outside board reporting to the vice president and to the dean of the appropriate college. These reviews will continue periodically thereafter, the period to be at the discretion of the dean but in no case at more than ten-year intervals(Committee_on_University_Priorities, 1973).

The 1973 report inaugurated a practice of formal strategic planning at the university based on systematic external evaluation of academic departments. This practice also was to have profound consequences for economics in the CHSS.

\section{Economics at UHS}

The introduction of economics as a teaching subject goes far back in UHS' history. The UHS historian mentioned earlier, who also served as associate dean of the CHSS, refers to a department of economics in the 1940s.Asacademic economics was increasingly influenced by the neoclassical paradigm and use of mathematical models in the second half of the $20^{\text {th }}$ century(Lawson, 2013; Seligman, 1962), economists at UHS did not embrace the movement. Although the teaching curriculum included courses grounded in 
neoclassical economics, UHS economists believed that, to align their research with the distinctive identity and mission of the university and Catholic Social Teaching (CST), they should emphasize issues such as social justice, poverty, labor, and development economics. This view was clearly articulated by John Goodwill, a Catholic economist who chaired the department between 1975 and 1984, and who has consistently criticized the Chicago School and its underlying positivistic view of economics in his writings. Goodwill went as far as to ask, in one of his writings, whether it is possible to be a Catholic and an economist.

As mainstream economics accommodated mathematics-based alternatives to the neoclassical paradigm(Colander, Holt, \& Rosser, 2003)and as mainstream economists secured control of key academic journals, research grant committees, and access to prestigious academic and policy jobs, the UHS department of economics in the College of Humanities and Social Sciences was progressively marginalized in the profession. Its members viewed their professional identity as more aligned with the minority of heterodox economists and with the distinctive identity of UHS.

The heterodox identity assumed by the department became increasingly problematic as the ambition to position UHS as a leading research university gained momentum. This objective, already expressed in the 1973 report on university priorities and strongly reinforced in the 1982 report on "Priorities and Commitments for Academic Excellence" submitted by the first lay Provost to the President, did not square with the economics department's consistently poor showing in national rankings.

\section{The research}

We first became aware of the situation in economics at UHS through reading a report in the media. Our curiosity was piqued. Although neither of us is an economist and neither of us has any tie to the university, we are both interested in the sociology of science in general and in the work of Thomas Kuhn on the significance of dominant paradigms in science and challenges to them in particular(Kuhn, 1962). On the surface, the situation in economics at UHS appeared to be an example of Kuhnian paradigmatic conflict. In fact, it proved to be that and more - a fascinating example of how isomorphic pressures shape organizational behavior and decision-making and how identity, interests, and power influence the adaptation process. 
The first phase of our research consisted of a search for publicly available evidence about economics in the College of Humanities and Social Sciences at UHS. We took many clues from coverage of the turmoil accompanying the structuration of economics in The Chronicle of Higher Education, The National Catholic Reporter, The Nation, The Observer, a UHS student newspaper, a student magazine, and in a blog started by students when they were majoring in economics at UHS.

In the spring of 2010 we interviewed professors representing the mainstream and the heterodox departments, university administrators, and students (details in Table 1). All but one interview with faculty and administrators were conducted face-to-face. Interviews with a student in his senior year and with a former student were conducted by telephone. All interviews were tape recorded. The names of all of the persons to whom we refer in the pages that follow and who are associated with the university, as well as the name of the university itself, have been changed for the purposes of assuring anonymity.

\section{Insert Table 1 about here}

Thanks to the interviewees and to the university's website, we were able to collect 88internal documents recording discussions and decisions about economics at UHS. Table 2 provides a list of these documents. Quotes from the various documents we cite are authentic; only the names referred to in the documents themselves have been changed to be consistent with changes in names noted above.

Insert Table 2 about here

Basing our analysis on these primary and secondary data, we developed a first draft of this paper and sent it back to all but two people (the two former students) we had interviewed in 2010, requesting factual corrections, comments on our interpretations, and a second interview on campus in 2011. We also sent the draft to two prominent members of the 'heterodox group', Peter Wiseman and Christian Marx, who were not interviewed in 2010. During our second visit to the UHS campus, in April 2011, we carried out seven interviews (Table 1, last column). 
While they offered a small number of factual corrections and invited us in some cases to nuance further our interpretation, our informants without exception agreed that out narration was, overall, factually accurate and interpretatively balanced. The second visit to the campus allowed us to see how the protagonists were adjusting to the new situation after the closing of the heterodox department and how they were reflecting back on the whole process.

\section{Conflicting narratives}

The first phase of our field work, conducted in April of 2010, was performed at a very sensitive moment in the structuration of economics at UHS. A month earlier, the Academic Council had voted in favor of the proposal submitted by the Dean of the CHSS to dissolve the department of Economics and Policy Studies, otherwise known as the 'heterodox' department, effective July 1, 2010.Understandably, the decision to dissolve a department that had been living under stress for seven years was strongly resented by members of that department. Some faculty and students viewed the decision as a violation of academic freedom, a threat to tenure, and a betrayal of Catholic Social Teaching. In their view, UHS would never achieve leadership in mainstream economics, mainstream economics was built on false assumptions, and UHS administrators' commitment to this type of economics reflected a growing influence of neoconservative ideology within the Catholic Church. On the other side of the divide, faculty working within the mainstream and university administrators objected that UHS could not afford to run two competing departments in the same discipline in the same College, could not afford to stay out of the mainstream, and that applying established research methods and publishing in the discipline's leading journals was not incompatible with studying topics close to the university's Catholic identity and mission.

The challenge for us as researchers has been to avoid taking sides and, instead, to develop an independent perspective on a highly controversial process. Conceptualizing the structuration of economics in the College of Humanities and Social Sciences at UHS as an evolving interplay between isomorphic pressures at an institutional level, and identity and power dynamics at the level of micro processes, has enabled us to craft a third narrative. 


\section{Responding to growing isomorphic pressures in economics}

The UHS response to the increasingly normative character of mainstream economics in US universities was lengthy and, at times, bitterly contested. From 1975 to 1982, economists at UHS were able to grow their department outside the mainstream with the support of university leaders. As the department's rankings did not match the aspirations of UHS's senior leadership to become a leading research institution, university administrators became increasingly concerned about its direction, and repeatedly invited its members to build capacity in mainstream economics by hiring appropriate faculty and publishing in leading journals. Such invitations, however, went largely unheeded, and a period of organizational paralysis in the face of the growing normative power of mainstream economics set in and lasted for about 15 years, from 1982 to 1997. In 1997, a new dean was appointed in the College of Humanities and Social Sciences. He put the situation in economics at the top of his priority list, intervening directly in faculty hiring and making it impossible for incumbent economists to dismiss pressures to publish in top economics journals as ideologically incompatible with CST. From 1997 to 2003, the department was asked to accommodate the mainstream without giving up on its heterodox identity. These efforts, however, did not bear fruit, and administrators subsequently forced a schism which led the College to have two rival and epistemologically antagonistic departments of economics (2003-10). The growth of the mainstream department and parallel decline of the heterodox department during this time paved the way for an outright dissolution of the latter in 2010 and enabled UHS to fully embrace mainstream economics.

What follows is a more detailed discussion of each phase and our analysis of how and why it took UHS and the CHSS such a long time to fully acknowledge and embrace mainstream economics, a path that other research universities followed much more rapidly.

\section{Act I (1975-1982): Deliberate Avoidance of the Mainstream}

Up to the early 1970s, the department of economics at UHS was "fundamentally a teaching department that was doing some research" (John Goodwill, interview). In line with the recommendations of "The Committee 
on University Priorities", the department underwent its first review in 1975. The reviewers found a department that was doing well in teaching, much less so in research, and was in need of direction.

The department presently is at a critical juncture in its development. Fundamental decisions concerning the future goals and direction of the Department, its leadership, its scope, and other fundamental policy determinations are in process...Fortunately for the Department, (it) has been able with the full enthusiastic endorsement of the University administration to settle upon a nominee whose background seems to fit perfectly the role which the Department and University need filled at this time.

John Goodwill, a prolific scholar, a committed Catholic, and an open critic of neoclassical economics, is the candidate alluded to by the external reviewers. He was recruited in 1975 to develop the department and give it the much needed intellectual direction advocated by the external reviewers.

Before joining UHS, John Goodwill held the rank of Full Professor at another prominent Catholic university, had chaired its department of economics (1969-71), and had published a good deal about the Soviet economic system and development economics. In 1975, the same year he moved to UHS, Goodwill published an essay in which he criticized the positivistic world view that underpins neoclassical economics.

When he was approached by UHS administrators, Goodwill expressed an interest in developing "a different department of economics with issues of ethics and justice at its core, not a mainstream program". Goodwill and university administrators shared the belief that direct competition in economics with Harvard or Stanford would not be a viable strategy for UHS. The department would rather focus on areas consistent with the university's commitment to Catholic Social Teaching (CST) such as development economics, labor and industrial relations, and policy. UHS economists would not be expected to publish in mainstream journals, as this would compel them to build on standard micro and macro-economic models. They would instead place their works in major applied field journals, as these were more open to epistemological and methodological diversity.

When we begin building the department anew after 1975 both we and the university had clear visions of what we wanted to do. The university vision for us as articulated by the president, the provost, and the dean was to build within Catholic social thought a program focused on policy issues. The department's vision was to argue that comparative advantage meant becoming the best not at what Harvard did but at what we might do through a focus on creating a graduate program that was different. We argued that given our potential resources (a department of 18-20 when top 20 departments averaged 35-45 faculty), 
our location in small town midwest, and even our Catholic affiliation would work against us if we simply tried to compete head to head. We argued that becoming ranked 40th didn't mean much. Instead, we emphasized: a/ a solid grounding in traditional economic theory and quantitative methods; $b /$ making available alternative approaches such as Institutionalism, Marxism, etc; and c/ drawing on the Catholic tradition to integrate ethical issues into the teaching of economics. There was no intention to say traditional economics was wrong, rather that it was not the only way to do economics (John Goodwill, interview).

Based on this understanding, Goodwill undertook a deep reconfiguration of the legacy department. He persuaded some members to retire, obtained new slots, and sought to recruit research oriented economists who would be "interested in doing something different". Convincing good candidates to move to a Catholic university and to a dying industrial town proved to be a tough job and "we were turned down by many good people" (John Goodwill, interview). Nevertheless, the department was able to attract and retain a core group of junior scholars who, together with Goodwill, would grow the department of economics outside of the disciplinary mainstream.

\section{Act II (1982-1997): Paralysis}

The 'out-of-the mainstream' direction and heterodox identity of the economics department became problematic after the appointment of the first lay Provost in 1978. A Princeton trained mathematician employed at UHS since 1962, the new Provost promoted a vision of UHS as "Princeton with Catholics". His ambition to transform UHS into a top research university was clearly articulated in a document titled "Priorities and Commitments for Excellence" (internally known as the PACE report) submitted to the President four years after his appointment. Academic departments would, from now on, be expected to come up in the top ten in their discipline. Those who did not achieve this ranking would come under pressure to improve.

For economics, improving the department's ranking meant engagement in the mainstream by publishing more articles in the discipline's key journals. Members of the department articulated four reasons for not following this path : 1) the mainstream was felt to be dominated by neoclassical economics grounded in an un-realistic view of human behavior, 2) the ideological foundations of neoclassical economics were felt to be incompatible with UHS mission and commitment to CST, 3) UHS would never be able to commit the 
financial resources or to attract enough talented mainstream economists to compete effectively with economics departments in big research universities, and 4) the world didn't need one more mainstream economics department.

Pressure to embrace the mainstream was clearly expressed in a review of the department carried out in 1988, as part of the new university-wide strategic planning process. Although the three external reviewers were, overall, sympathetic to the department's intellectual orientation, they nevertheless wrote that:

The Department appears to have made slow progress toward adaptation to a changed institutional environment where increased emphasis is being placed on research excellence relative to the traditional emphasis on undergraduate teaching excellence.

With regard to the department's intellectual orientation and its consequences for its standing in the discipline, the reviewers:

... agree with the Department's proposed strategy to continue in its commitment to social justice and its openness to alternative approaches. However, they caution that the risk is high that the desired national recognition will not be achieved unless research leads to more fundamental publications in the mainline journals.

The most mainstream member of the evaluation panel, challenged the department's rejection of mainstream economics:

There is only one way to achieve recognition as a serious economics department and that is through refereed publications in those journals that economists recognize as leading journals. The profession has a fair amount of agreement on which journals these are and is quick to pick up on recent additions to the list. Most of us reject the argument that the mainstream journals are narrow or biased or less than hospitable to alternative approaches. We do use a common language and for the most part begin with a common approach - optimization subject to constraints - and we apply this to issues until and unless it is found wanting. Where the approach is found wanting we welcome alternatives but we still insist on rigorous models with testable implications.

Later in his review, he wrote:

I would not recommend a major change in direction, but rather a modest tilt toward mainstream economics. I would add resources but in doing so would insist that more time and attention be devoted to the undergraduate program, primarily by current faculty whose interests and skills are in the undergraduate program. In terms of graduate core courses, I would look to new hires who demonstrate through their interests and background that they will be training research economists who can interact on the frontiers of the discipline. 
Five years after the 1988 review, the department was ranked $81^{\text {st }}$ (out of 108) by the National Research Council while UHS, as a whole, was ranked $18^{\text {th }}$. Instead of recruiting mainstream economists, the department had reinforced its heterodox professional identity. Peter Wiseman, a post Keynesian economist trained at MIT, joined the department in 1988. Wiseman had gained tenure at another university and published a good deal in the area of development economics using mathematical models. Charles Binder, a prominent critic of neoclassical economics, was offered an endowed chair in 1990.

How did the UHS economics faculty manage to maintain the status quo despite consistent pressure from the Provost, external reviewers' recommendations, and unfavorable rankings? Our analysis of the micro processes that underlay this situation strongly suggests that identity dynamics and power differentials played a key role. From the point of view of the small group of economics professors who were active in research, there was alignment in the status quo between their professional identity, the identity of the department and the identity of the university. This perception of alignment served as a shield against the growing dominance of the mainstream in the economics profession. The emergence, at the same time, of alternative academic forums and publication outlets, such as the Association of Socio-Economics, enabled UHS heterodox faculty to maintain their sense of belonging to the economics profession and differentiate themselves from mainstream economists.

Why did administrators fail to force the heterodox department to heed the mainstream for so many years? First, heterodox economists had a strong ideological case. They were able to claim that the research they were doing was consistent with Catholic Social Teachings, without being challenged on this assumption. Having the ideological upper hand, they were able to portray attempts to change their research agenda as a betrayal of the university's mission. Second, the first lay Provost was keen on enhancing the university's overall research profile, and being at the periphery of the College of Humanities and Social Sciences, the economics department was not at the top of his list of priorities. A former dean suggested that the department could grow in its own way, below the radar, because economics was not central in the CHSS, where theology and 
humanities occupied the core and were more closely scrutinized. Third, the department could continue to ignore the mainstream thanks to its affiliation with a college where deans were typically appointed from inside, served for limited terms, had personal ties to faculty members, and lacked the power to force top down change on the department.

\section{Act III (1997-2003: Failed Attempts at Evolutionary Compromise}

In 1997, one year into the tenure of a new Provost, Jeffery Wood, another external review of the department of economics was conducted by a panel of three economists. As part of the review process, the Economics Department, then chaired by Peter Wiseman, prepared a self-study report which ended with the sketching of a strategic plan where one can read:

To improve the reputation of the graduate program and to improve the visibility of its faculty in the profession, the Department needs to engage the mainstream of the profession by participating in discussions and debates in relevant branches of economics, and by publishing in leading general and field journals in economics and with major book publishers. The department also needs to provide a range of core and elective courses that provides rigorous training to graduate students in economic theory and quantitative techniques. This is because graduates in economics - perhaps more so than in other social sciences - are judged by their overall training in addition to their expertise in their fields of specialization(Economics_Department, 1997).

The report prepared by the reviewers was openly critical of the department's intellectual orientation and research output, as measured against the profession's dominant standards.

In summary, we found the scholarly environment to be less rich than it should be, in light of the resources available, the national ranking of the university and the aspirations of virtually all concerned. As one visible manifestation of the existing scholarly environment, the department's research output is, on the whole, modest. With a few exceptions, faculty are not producing enough research of publishable quality, a fact that many faculty readily admit. What is published rarely appears in prominent refereed journals. The low overall quality of research appears to result from a combination of factors, including distance from (and in some cases, antipathy toward) the world of grant-supported, conference-attending, and article-writing economists at major universities, most of whom either use or are very familiar with neoclassical models and/or statistical methods of analyzing economic data. To be sure, not all of the economists in this world subscribe fully to all of the assumptions of the neoclassical model, but they are at least ready and willing to engage other economists on these terms, and that means publishing in the leading journals.

The external review committee recommended that the department seek a better balance between its heterodox orientation and participation in mainstream economics. 
Our overall conclusion... is that the economics department should broaden its intellectual portfolio. Without abandoning its traditional interests in heterodox theory and socially-relevant research, the department should strive to add faculty and to restructure its graduate program in order to play a more prominent role in the economics profession and in domestic policy debates.

The committee recommended that the department recruit one or two chaired professors with a strong research record in mainstream economics who would then attract more mainstream junior faculty. To overcome the difficulty of agreeing on candidates, due to the highly democratic governance of the department, the reviewers recommended establishing an external advisory committee to help with the screening of candidates to the department.

A few months later, in the fall of 1997,Paul Hatch, a Catholic professor of literature at a major state research university, was appointed new Dean of the College of Humanities and Social Sciences. A driven and outspoken scholar, Hatch made a clear commitment at the beginning of his tenure to "address previously neglected disciplines and problem areas". Economics was at the top of his list.

Very early in his tenure as Dean, Hatch articulated a "Triadic Identity' for the University of the Holy Spirit "as a residential liberal arts college, a dynamic research university, and a Catholic institution of international standing". Instead of viewing the university's Catholic character as a liability for hiring top scholars and developing world class research, Hatch advocated a more proactive strategy where Catholicism would be used as a resource for attracting outstanding students and faculty in search of an environment where they could reconcile their spiritual life with professional achievement.

With regard to economics, Hatch was the first dean to challenge openly the assumption that research in mainstream economics would be incompatible with the university's identity. He made this view very clear in notes prepared for his first formal meeting with the economics faculty in November 1997.

The most central issue that has come out of the (1997) review is the need to raise the scholarly reputation of the department... We expect departmental faculty to employ the full array of tools of the profession in order to address issues relevant to UHS and to address them in the most outstanding and most read journals...Socially-relevant work that does not satisfy professionally-acceptable quality standards has little or no value in terms of academic scholarship...Bottom line: A departmental profile is welcome, but high standards are necessary. One must meet the standards of the profession and publish in quality journals. 
To assist him in the implementation of the external review recommendation to recruit senior mainstream economists, Hatch set up an external advisory board with four UHS economics graduates who were pursuing successful careers at leading universities. This initiative did not prove to be terribly effective. Members of the economics department blamed the failure of recruitment efforts on the dean, whom they suspected of not being genuinely committed to the development of the existing department. Christian Marx, one of the leading figures of heterodox economics at UHS, wrote in 2003:

Hiring has been taken out of the hands of the department since 1998. The members of the department have done their best to suggest candidates, participate in the activities associated with campus visits, and conduct deliberations in department and CAP meetings - all in an atmosphere in which only recommendations that coincided with those of the dean and appointed search committees were considered valid.

The Dean, in turn, blamed the department for a hostile attitude toward mainstream candidates and for not recommending strong ones. According to Hatch, senior Catholic mainstream economists declined offers to join UHS until there would be a "true" economics department. This view was expressed by then Provost Jeffery Wood at a meeting of the Academic Council held on February 18, 2003 to discuss the situation:

Prof. Wood said while it is difficult to pinpoint the exact reasons for the candidates' refusal, three things did emerge in his discussions with them. First, the candidates did not want terrain that was too contested ... Second, in some cases, the candidates reported a coolness by departmental faculty towards them or said they felt the department was so contentious that it would not be a good home. Third, the issue of quality was raised - there was not a critical mass of mainstream economists in the department. Within this group of candidates who declined UHS offers, Prof. Wood said, the hardest case for him was a mid-level appointment offered to a candidate... who is Catholic and had many reasons to look at UHS. (His) research focus is the moral and social dimensions of microeconomic behavior in low-income communities in Africa. He was the perfect candidate, but he went to (another university) instead - saying that there was not sufficient support at UHS at the midpoint of his career to proceed with his work here(Academic_Council, 2003b).

The first mainstream neoclassical economist with a strong research orientation was recruited in the fall of 2001. James Fletcher, who held an endowed professorship at another university, accepted an offer from UHS after his wife's appointment as Associate Director of the Library at UHS. At Paul Hatch's initiative, Fletcher was recruited in the department and within a year was appointed as department chair without the support of a majority of department members. 
The appointment of James Fletcher was deeply resented by a majority of department members as a case of top-down interference in a department used to democratic decision making. We heard different views on why life in the department deteriorated to a point of loss of civility, in some instances. Incumbent members of the department blamed it on James Fletcher's presumed polarizing personality, while he and Dean Hatch viewed the escalation as resistance by members of the department to inevitable and painful change. We propose a third explanation, in line with our argument about the interplay between identity and power in responding to isomorphic pressures. From the point of view of those members of the department who opposed mainstream economics, moving toward the mainstream meant violating their deeply established professional identity as either critics of neoclassical economics or as economists engaged in policy-related work. For this reason, growing mainstream economics within the department was bound to be met, at best, with indifference and, at worst, with open hostility. Although some members of the department had good training in quantitative techniques and were active in research, doing mainstream economics would have gone against their deeply seated sense of who they were and how they were viewed in the academic community. Since their professional identity defined them in opposition to the mainstream, allowing its development would have meant loss of influence, as a new group of economists clearly identified with the mainstream would have to be brought into the department. Although they may have been intellectually convinced of the need to make room for neoclassical economics, as the 1997 self-study shows, their professional identity did not enable incremental accommodation. Instead of broadening the department's epistemological and methodological spectrum, these identity issues turned the e

Economics Department, in the words of one interviewee, into a battlefield where a 'heterodox' majority was locked in a struggle for the soul of economics at UHS with an 'orthodox' minority which enjoyed strong support from administrators but could not change the face of a department which had been accustomed to selfrule. 


\section{Act IV (2003-10): Schismatic Compromise}

In the fall of 2002, in an effort to find a way out of the deadlock, Provost Jeffrey Wood appointed five senior professors from different departments to serve on a Blue Ribbon Committee (BRC) to study the situation in economics and make recommendations. In the report submitted to the Provost in November 2002, the BRC concluded that differences within the department were irreconcilable and made a radical proposal to split economics into two departments

...We regard the differences between the heterodox and orthodox economists to be so great that reconciliation within a single cohesive department is wholly unrealistic. The differences in assumptions, methods, and paradigms are simply too great to overcome. Thus, while we did consider other possible solutions such as retaining the status quo, or putting the Department in so called "receivership", we do not consider these to be viable long-term solutions (Blue_Ribbon_Committee, 2002).

The $\mathrm{BRC}$ recommended renaming the existing department as the "Department of Economic Thought and Policy" and creating a new "Department of Economics" committed to teaching and research in mainstream economics. The graduate program would be placed under the responsibility of the new department, but would be suspended until the new department was able to offer a full-fledged graduate curriculum in economics. The undergraduate curriculum would be the joint responsibility of the two departments.

The BRC recommended that members of the existing department, and faculty from other parts of the university, be able to apply to the "Economics Department" but the "invitation" would be made by the Dean or Department Chair. In this way, the new department would be allowed to choose faculty whose research was aligned with mainstream economics. To grow the new department, the BRC recommended the immediate addition of 5 to 7 new faculty positions.

The $\mathrm{BRC}$ recommendations were rejected by 15 out of the 20 tenured members of the department. The opponents took their case to the College Council and to the Academic Council and made a counter proposal to:

- Establish an Institute of Applied Economics and Econometrics, in order to attract and retain high-quality mainstream economists. 
- Make a series of junior hires, in order to change both the generational profile and the research record of the department.

- Hire prominent senior and endowed-chair candidates in mainstream economics, especially those who are interested in working in a department characterized by intellectual diversity.

- Devise a two-track Ph.D. program-one in Applied Economics and Econometrics, another in Political Economy - to attract the highest quality students for graduate training in economics.

- Conduct a promotional campaign, inside and outside the university, which focuses on and advertises the strengths of the department.

- Hire a new chairperson and/or establish a representative executive committee, to chart the future of recruitment and curriculum for the department.

The internal discussion took on a national dimension as The National Catholic Reporter (NCR) and The Chronicle of Higher Education (CHE) took interest in events surrounding economics at UHS. The CHE published a long story on the situation in economics at UHS in January 2003 where the reporter wrote:

...The University of the Holy Spirit's economics department, long renowned as unusually diverse, is likely to split in two. A new department of economics, with a graduate program and several new hires, would focus on orthodox approaches.

Dissident economists would be consigned to a department focusing on economic thought, social justice, and public policy. But with no graduate program, that would amount to exile and slow death, say the Marxist, labor, and development economists and historians of economic thought who make up a large minority of the 21-member department.

Opposition to the split came from unexpected sources such as a Nobel Prize winner who advised the President of UHS against the decision. After apologizing for "sticking (his) nose in other people's business", he wrote:

You should know that I am a mainstream economist, in fact a mainstream mainstream economist. But I am not an uptight mainstream economist. Economics, like any discipline, ought to welcome unorthodox ideas, and deal with them intellectually as best it can. It does pretty well, in fact. To conduct a purge, as you are doing, sounds like a confession of incapacity. I grant that you are not shooting the Trotskyites in the back of the head, but merely sending them to Siberia, That is not much of an improvement.

A prominent heterodox economist published a vitriolic indictment of the UHS administrators involved in the process. 
What's the problem nowadays at UHS? ... The Dean of the College of Humanities and Social Sciences, one Paul Hatch, together with his agent in Economics, James Fletcher, and with the backing of the Provost, Jeffrey Wood, and the apparent entrepreneurship of the Dean of the Graduate School has decided that UHS' Econ Dept is broke ... and should become mainstream...The Department has resisted. It's being punished with appointments imposed on it; its promotions have been turned back. It may be abolished entirely, its distinctive graduate program scrapped, and a new one started that will be drearily Samuelsonian.

Efforts to oppose the implementation of the BRC recommendations won support from a large majority (25 to 14 votes) of members of the College Council on January 29, 2003(Cunneen, 2003a). The Faculty Senate voted in the same direction. However, as the College Council and the Faculty Senate have a purely advisory role in the university's bylaws, the votes were not binding.

While external and internal opposition did not deter university administrators from implementing the BRC recommendations, some compromise was needed before the Academic Council, the highest decision making body chaired by the President, would be asked for a final determination. On March 20, 2003, the Academic Council voted on the following motion:

The University should create a Faculty of Economics under which there are two separate and distinct departments. One will be the existing department, which will be renamed 'Department of Economics and Policy Studies,' and a new department will be created and known as 'Department of Economics and Econometrics.' Each department will have its own chairperson and its own Committee on Appointments and Promotions, and its own standards and procedures for appointment, tenure, and promotion. The tenure of the tenured members of the existing department will be protected(Academic_Council, 2003a).

As could be expected because of the claims to identity it raised, naming the two departments proved to be tricky. Allowing only one department to use economics in its name, as the BRC recommended, would have implied that heterodox faculty members were not economists and would have undermined their professional identity. The compromise enabled both groups to claim professional identity as economists. To cope with the fact that CHSS would have two departments of economics, Dean Hatch proposed the creation of a "Faculty of Economics", an empty shell that would be used to communicate disciplinary unity to undergraduate students.

The compromise also involved the suggestion made by Dean Hatch that separation would enable each group to flourish in its own way and that additional faculty recruitment would happen when the two departments reached equal size. 
...because the University must increase the number of mainstream economists on its faculty, a likely scenario will be that if departures occur in the proposed Department of Economics and Policy Studies, those lines would go to the Department of Economics and Econometrics until the two departments are of equal size. When they are of equal size, it will be time to look at other issues and arguments on behalf of the department for keeping its lines. In the immediate future, however, Prof. Hatch said, the size of the new department needs reinforcement. (Academic_Council, 2003a)

The suggestion was reinforced by the President in his closing remarks after the vote.

The President said that while he has refrained from giving his views on the matter, he is deeply committed to the goal of trying to find a balance in the department and allowing both units to flourish.(Academic_Council, 2003a)

Implementation of the proposal led each department to engage in identity work and articulate for itself an identity that would clearly define who it was and how it differed from the other department. The Economics and Econometrics department was defined by its members in the following paragraph:

Our mission is to achieve and to sustain excellence in research and teaching at both the undergraduate and graduate levels. We are a neoclassical economics department(emphasis added) committed to rigorous theoretical and quantitative analysis in teaching and research. Members of our department have specialties in the areas of micro and macro theory, econometrics, labor, monetary, international, and environmental economics (departmental website).

Members of the Department of Economics and Policy Studies proposed their own definition of the identity of their department.

Committed to values and socio-economic justice. Open to alternative theories and approaches. Interested in devising effective policies. Providing students with solid training in economics that matters (saved from the departmental website, closed in July 2010).

Each group also sought to articulate how it fit with the distinctive identity of the university. Members of the

Department of Economics and Econometrics came up with the following:

Guided by the University's long-standing commitment to the Catholic social tradition, we stress policyrelevant research that contributes to important debates on economic, social, and political problems facing humanity (departmental website).

Members of the Economics and Policy Studies also emphasized their alignment with the university.

This distinctiveness is related to the Catholic identity of the University of the Holy Spirit and is reflected in the research activities of the Department's faculty and in the courses offered to undergraduate and graduate student (saved from the departmental website, closed in July 2010) 
The new Economics and Econometrics department embraced the strategic plan developed in June 2002 by James Fletcher for the old Department of Economics. The plan had been developed as part of a university wide strategic planning exercise driven by five imperatives including "a heightened sense of urgency for the centrality of research and scholarly publication"(Strategic_Planning_Coordinating_Committee, 2003). The key element of Fletcher's plan was that the CHSS would need a department of economics with 30 tenure track faculty members(ECOE, 2003). The first five members, including James Fletcher, who was appointed as chair of the new department, were recruited from the old department. As of January 2014, the department counted 29 full members and two joint appointments with the College of Business.

Taking seriously the Dean's statement in several meetings that "a split is the best way for the nonparadigmatic faculty to flourish" (Cunneen, 2003b), members of the Department of Economics and Policy Studies submitted to him, on their own initiative, a strategic plan reemphasizing their commitment to intellectual diversity and recommending three recruitments in "Religion, Ethics, and Economics", "Political Economy of Conflict and Rebuilding", and "Economic History" (ECOP, 2003).Instead of growing, the department lost six of its 15 positions mainly due to retirements and two resignations. While Christian Marx and Mary Bowden were promoted to full professor in 2005, no other members were promoted to full professorship. Soon after the split, Catherine Reed, then an associate professor, moved back to Europe and is currently Professor of Economic Theory and Policy and Chair of the Department of Economics at a Dutch university. Mary Bowden left UHS in 2007 for a chair at another US institution.

Developments following the split of economics into two departments served only to exacerbate identity issues rather than resolve them. The idea that separation would allow serious, proactive engagement in mainstream economics without reneging on the university's historical commitment to heterodox economics proved untenable, and served only to create ambiguity both internally and externally.

What enabled the triumph of mainstream economics and the decline of the heterodox legacy? Some informants put the redirection of economics at UHS in the context of the rise of the "right" at the expense of the "left" within the Catholic Church and the university. Even if that were true, it would certainly not be the 
whole story. Paul Hatch, who played a central role in the process as dean of the CHSS, can hardly be categorized as a neoconservative. At the time he was driving the reconfiguration of economics at UHS, he published an Op-Ed in a prominent national newspaper where he provided a moral argument for American Catholics to support Democrats for their anti-war stance and despite their liberal positions on abortion. The heterodox economists at UHS got caught in the clash between what had been and what was becoming the kind of economics research that would suit the ambition of the university to be a first class national research institution. Paul Hatch was the first Dean to challenge openly the belief that mainstream economics was incompatible with UHS' preoccupation with social justice.

The most powerful argument against change... has been the argument that Catholic economists working on social justice issues "cannot and should not" publish in the leading mainstream journals of the discipline. Given the impact of these top journals... our economists should publish there; otherwise, their voices will not be heard. They can publish there because top journals are interested in social justice questions. The American Economic Review, for example, regularly publishes articles on social justice issues.

By challenging the association of heterodox economics with the identity of UHS and arguing that the principles and methods of mainstream economics, when applied to social justice issues, were compatible with UHS' Catholic character, Hatch, together with Fletcher, called into question the deeply established ideological hegemony of heterodox economics within the university. According to Hatch, this view was shared by senior professors in other departments who did not express it publicly.

One social scientist outside the Department of Economics wrote to me "The real problem in the Department is the failure to reach standards that are far ahead of most faculty. The problem is not orthodox vs heterodox approaches, it is not quantitative vs non-quantitative methods, and it is not 'sacred' economics $v$ s 'secular' economics. The real problem and only problem is quality of scholarship." Our colleague continued: "Any one of the articles in the issues of AER that were circulated at the meeting could be thought of as a social justice issue."

Dean Hatch also challenged the intellectual diversity argument, effectively turning it against the heterodox group.

Currently, the Department is insufficiently diverse. It has not been open over the years to cutting-edge mainstream economists... and its areas of thematic interest have been unduly narrow. Diversity works in both directions. Unfortunately, although intellectual debate is presented as a major issue in this 
discussion, senior candidates (to the department) suggest that very few questions are asked of them about their own research. Instead, they are asked whether they are supportive of heterodox economics and whether they would apply the standards of the discipline at UHS.

The charge against heterodox economics found its ultimate support in the poor ranking of the department, compared to other departments in the College of Humanities and Social Sciences.

Although the Department has articulated in exemplary ways a vision appropriate to UHS, with its emphasis on social justice issues, it has not as a whole kept pace with the theoretical and econometric tools needed to address these challenges. The result in the last National Research Council evaluation was a 1.53 rating in academic quality (on a 5.0 scale), the lowest in the College of Humanities and Social Sciences by far. The next lowest department received an academic quality rating of 2.63.(Dean Hatch, memo)

While the critics of mainstream economics challenge the foundations and methods of the rankings, and some promote alternative rankings where UHS' heterodox economists compare more favorably (Lee, Grijalva, \& Nowell, 2009), the old economics department did not have a strong case. Christian Marx's critique of the intent to split the department to enable the growth of mainstream economics ironically highlights the problem.

It is true that the publishing record as a whole could be stronger. The "older" generational profile of the department (there is currently 1 assistant professor) means that a minority of the faculty (again, both mainstream and heterodox) does not have an active publishing record-but the members of this group have made (and continue to make) valuable contributions to the department and university, through administration, service, and especially teaching.

The old economics department was able to thrive on a sense of alignment with the identity of UHS and this sense of alignment enabled its members to ignore or minimize pressure from university leaders seeking to enhance research productivity. The appointment of Paul Hatch, an outsider unconstrained by the obligations of friendship and loyalty and an advocate of Catholic scholarship, drove a wedge in this alignment. Ideological alignment with and support from Jeffrey Wood in the Provost's office tilted the balance of power in favor of administrators. The combination of strong leadership in the Dean's office for ten years and the increased normative power of mainstream economics in higher education, in general, over whelmed UHS' heterodox economists, who found themselves swimming upstream, in the face of a formidable tide. 


\section{Act V (July 2010-): Full Acquiescence to the Mainstream}

Stephen McGuire, a UHS historian who succeeded Paul Hatch as Dean in 2008, shares the ideological orientation and personal drive of his predecessor. One year into his tenure, McGuire submitted a proposal to the Academic Council to dissolve the Economics and Policy Studies department and affiliate its members, on a case by case basis, with different departments and institutes across the university. McGuire's main rationale for the proposal was that the mainstream department was "doing extremely well in terms of recruitment and research output" and that the Economic Policy and Studies department would never be permitted to hire new faculty.

This proposal raised another, although weaker, wave of protest from faculty(ECOP, 2010)and students, and attracted considerable media coverage. McGuire did not submit the proposal to the College Council, which had voted against the split in 2003. The Faculty Senate discussed the matter and voted against the dissolution of the Economics and Policy Studies department on the grounds that it would violate academic tenure.

Tenure includes protection against removal of a faculty member from a continuing department without his or her consent, barring demonstration of serious cause for removal.... Should a Department of Economics be reestablished at UHS, faculty members tenured in the original Department of Economics should be allowed, if they so choose, to be members of that department(Faculty_Senate, 2010).

The student government expressed concern about the dissolution and voted against it:

Students are concerned that closing the department will narrow the economics education at UHS... They are also concerned that this decision sets a precedent that students will be excluded from future academic decisions.

Opponents of the proposal lost the battle as the Academic Council approved the resolution in February 2010. The Economics and Policy Studies department was officially closed as of July 1, 2010.

Four of the nine members of the closed department became affiliated with institutes and had no departmental affiliation. Two retired. One became a Professor of Economics "at large". The other two found departmental homes: Peter Wiseman in the Political Sciences Department and George Butler in the Department of Economics. The name of the former "Department of Economics and Econometrics" was changed to the 
"Department of Economics" The disbanding of the heterodox group and the forced reunification of economics within a single, mainstream, department was the final step in the long march of UHS' leaders to embrace mainstream economics after several decades first of avoidance and subsequently failed attempts at compromise.

Compared to fierce opposition to the split in 2003, the closing of the department met relatively little resistance, as the heterodox group continued to lose influence. At the same time, the mainstream department enjoyed relative success, by mainstream academic standards, and recruited a group of scholars who use mainstream research methods to study topics relevant to Catholic Social Thought. Members of the former Economics and Policy Studies department, worn down by the long struggle, realized that they were on the weaker side of the issue and did not invest as much energy as they had in 2003 to oppose what by then appeared to be inevitable.

\section{Micro processes and isomorphic adaptation}

Isomorphism is at the core of institutional theory whose central premise is that organizations are subject to mimetic, normative, and coercive pressures that make them look similar to other organizations as they seek to change (Walter W Powell \& DiMaggio, 1983). The deterministic tone of the central premise has generated a line of research where scholars sought to reconcile the primacy of institutional forces with a significant dose of organizational-level agency in dealing with them (Oliver, 1991).

Oliver outlined five strategies for coping with institutional processes: acquiescence, compromise, avoidance, defiance, and manipulation, and formulated ten theoretical propositions linking five dimensions of an institutional process (cause, constituents, content, control, and context) to the focal organization's response to predict which strategy a given organization would adopt. Her key theoretical insight, i.e. organizations may respond to isomorphic pressures in a variety of ways, found support in subsequent empirical studies. Ang\& Cummings (1997), for example, investigated the effect of institutional influences on IT outsourcing by US banks and found that "the propensity of banks to conform to or resist institutional pressures depends on the 
nature of institutional pressures, perceived gain in production economies, financial capacity to resist institutional influences, and transaction cost considerations". McKay (2001) studied organizational responses to the enactment of an Environmental Bill of Rights in Ontario, Canada and found support for the interactive nature of organizational responses to external pressures. Clemens \& Douglas (2005) used the framework to investigate how firms in the steel industry dealt with the important issue of radioactive contamination of scrap steel. Among their findings, "firms that cooperated with others in their industry favored less active firm strategies and were less inclined to engage in the actively resistant strategies of avoidance and defiance". Ramaneh(2009) studied the possible isomorphic consequences of dealing with the state for three nongovernmental organizations (NGOs) operating in the state of Maharashta, India. Contrary to the standard internal structural isomorphism prediction, the author found that "NGOs use different tactics in response to the same public policy environment”. And Randel et al.(2009)combined stakeholder, organizational identity, and the strategic responses literatures to specify how organizational identity influences an organization's responses to negative evaluation in the public domain by external stakeholders. The authors found that "the number of identities possessed by an organization and the level of perceived organizational identity threat affect which type of response an organization will adopt".

While Oliver's framework stimulated a good deal of empirical research on organizational responses to institutional processes, most of that research is cross-sectional and treats organizations as if they were unitary actors pondering institutional pressures and weighing alternative response strategies. Organizations, however, are not unitary actors. What is more, they are not static. They evolve and change, and cross-sectional "snapshots" fail to capture the dynamics that undergird their evolution(Kimberly \& Bouchikhi, 1995).

Our observations of how faculty, deans, and university leaders coped, over a period of 35 years, with the increasing normative power of mainstream economics show how micro processes shape institutional responses, responses that vary over time as a function of members' understanding of their own and of the organization's identity and by the balance of power among them (Delmas \& Toffel, 2008; Randel et al., 2009). The data we collected highlights evolving interpretations of the kind of economics scholarship and 
professional identity that suit the Catholic character of UHS. The transition from one phase to the next shows a slowly shifting balance of power in favor of the advocates of full embrace of neoclassical economics, a shift that required forceful leadership to complete.

Our analysis of the multi staged and bitterly contested mainstreaming of economics at UHS extends in important ways Oliver's theorizing about strategic responses to institutional processes. The analysis supports the claim that institutional processes do not automatically produce organizational outcomes (Oliver, 1991; Walter W. Powell \& Colyvas, 2008) and that different organizational identities may induce different responses to the same institutional processes (Kipping, Usdiken, \& Puig, 2004).Mainstream economics acquired a "force of law" at UHS only as university administrators articulated and escalated their commitment to developing the research profile of the university as measured in increasingly normative rankings and as a new dean allocated significant attention (Ocasio, 1997) to the situation of economics where the mainstream weighs heavy. One could easily imagine that a different strategy, with less emphasis on academic distinction in areas where UHS chose to pursue an alternative course to the mainstream, would have enabled UHS' heterodox economists to continue to work outside the mainstream.

UHS did not resort to the defiance or manipulation strategies suggested by(Oliver, 1991) in the face of growing dominance of mainstream economics. While a few 'heterodox' professors, mainly Charles Binder and Christian Marx, adopted an openly defiant epistemological posture in their publications as pressure grew on the 'heterodox' department to embrace the mainstream, the official faces and voices of UHS never expressed open criticism (defiance) or attempted to influence the evolution of the economics profession (manipulation) in a more 'Catholic-compatible' direction. UHS lacked the symbolic and material resources necessary to support open defiance or epistemological manipulation of economics. As a 'faith based' university operating in an extremely secular sector, UHS is not well placed to set the agenda for economics. Any attempts to defy mainstream economics and articulate a 'Catholic' alternative would suffer from an identity liability and in all likelihood would not be taken seriously by the discipline's stakeholders. Consistently low rankings of the legacy department would not have enabled UHS to promote a credible 
alternative to mainstream economics, a strategy that is more viable for central members within mature institutional fields (Greenwood \& Suddaby, 2006). Finally, its modest financial means would not have allowed UHS to recruit and retain a significant number of 'heterodox' economists who publish high quality work, by mainstream standards, and who may have won distinctions, such as a Nobel Prize, that would enable them to challenge the neoclassical foundations of most of what is published by mainstream economists.

While UHS lacked the resources to defy or manipulate mainstream economics, acquiescence came about very slowly and through a highly contested and complex process. Opponents to full acquiescence whose a) individual, professional and organizational identities were challenged, and b) relative power and influence in the organization were threatened by these norms had positive incentives for avoidance and maintenance of the status quo. For professional isomorphic pressures to produce change at UHS, the process needed internal advocates who were forceful enough to overcome opposition and redefine the organization's identity in such a way that the process would not be seen as selling the organization's soul. Absent such forceful exercise of power, the result would have continued to be organizational paralysis, as was the case in the long period where UHS administrators wished for the department to accommodate the mainstream but had little leverage to motivate change in its direction.

The longitudinal investigation of economics at UHS has enabled us to identify an additional type of response to isomorphic pressures that we call organizational paralysis.From1982 to1997, university leaders were increasingly aware and concerned about the growing gap between UHS's heterodox department and dominant professional norms. However, they lacked the power to force the department to acknowledge the evolving disciplinary landscape. Paralysis, as an organization's response to isomorphic pressures, differs from the other strategies outlined by Oliver (1991) in one major respect: organizational leaders want to align with isomorphic pressures but lack the power to act.

Our research also enables us to identify two possible organizational modes of compromise with isomorphic pressures: evolutionary and schismatic. For five years, the leaders of UHS urged and expected the legacy department to accommodate mainstream economics without necessarily giving up on its 'heterodox' 
orientation. While evolutionary compromise would have enabled UHS to participate in economics scholarship in a more pluralistic way, it proved impossible as members of the legacy department became enmeshed in a sort of identity trap (Bouchikhi \& Kimberly, 2003) and saw compromise as a threat to their professional identity and standing within the department, college, and university. Schismatic compromise was promoted by UHS leaders as a last resort option and created an awkward situation where the university had two competing departments in the same discipline in the same college.

Our analysis further shows that acquiescence is hardly a passive process whereby an organization merely adopts institutional norms. Although they decided to embrace the mainstream, UHS leaders and 'mainstream' economists have also sought to connect with the university's Catholic character and interest in social justice issues. Empirical manifestations of a 'mainstream economics à la UHS' are the recruitment of Catholic faculty and their engagement with 'social justice' topics such as poverty, health economics, labor, family economics, and development.

Finally, analysis of the micro processes that led ultimately to the decision to disband the Department of Economics and Policy Studies showed how complex organizational response to isomorphic pressures is in practice. Organizations do not respond in a single stroke and as a single agent. Because organizations are political arenas where actors carry different identities, develop divergent interpretations of isomorphic pressures, and pursue conflicting agendas, organizational responses can and do vary with time as a function of shifting identity dynamics and power differentials.

When an organizational change triggers deeply-rooted identity conflicts (Fiol, Pratt, \& O'Connor, 2009), as was the case at UHS between heterodox and mainstream economists, forceful exercise of power is required to tilt the balance one way or another. The appointment of Paul Hatch as Dean of the College of Humanities and Social Sciences was crucial. Until Hatch's appointment, the college was led by deans appointed from within, who did not stay long in the Dean's Office, and who interfered little in the conduct of departmental affairs. A committed, articulate, and outspoken Catholic scholar coming from a major research university, Hatch was free from the traditional loyalties that deans appointed internally may have to their former colleagues. He 
challenged the long held claim made by heterodox economists about the incompatibility of UHS' Catholic identity with mainstream economics. His intensive sense making and sense giving work (Gioia, Thomas, Clark, \& Chittipeddi, 1994)on the triadic identity of UHS and efforts to prove that the methods of mainstream economics are not incompatible with the substance of Catholic Social Teaching illustrate the intrinsically political character of identity claims (Rodrigues \& Child, 2008). After five years of pressure on the legacy department to recruit mainstream economists and broaden its identity, Hatch became persuaded that a split was necessary. Weak faculty governance at UHS, where the college council and faculty senate have mere consultative voice, and consistent support from Provost Jeffrey Wood made the split possible, despite hostile reactions from within and outside the university. Hatch's persistence created the conditions of full embrace of the mainstream under his successor, Stephen McGuire, who met less opposition in closing the heterodox department and allowing the mainstream one to define itself as the sole department of economics at UHS. Perhaps the most profound irony is that while mainstream economics was winning the battle over the soul of economics at UHS, critiques and threats to its dominance on a broader scale outside the University were becoming increasingly visible. The story, therefore, is hardly over. 


\section{References}

Academic_Council. (2003a). Meeting of Academic Council.

Academic_Council. (2003b). Minutes of the Academic Council meeting, February 18.

Albert, S., \& Whetten, D. A. (1985). Organizational Identity Research in Organizational Behavior (Vol. 7, pp. 263).

Ang, S., \& Cummings, L. L. (1997). Strategic response to institutional influences on information systems outsourcing. Organization Science, 8(3), 235-256.

Blue_Ribbon_Committee. (2002, December 9). Report of Blue Ribbon Committee on Department of Economics

Bouchikhi, H., \& Kimberly, J. (2003). Escaping the Identity Trap. Sloan Management Review(Spring), 20-26.

Clemens, B. W., \& Douglas, T. J. (2005). Understanding strategic responses to institutional pressures. Journal of Business Research, 58(9), 1205-1213.

Colander, D., Holt, R., \& Rosser, B. (2003). The Changing Face of Mainstream Economics. MIDDLEBURY COLLEGE ECONOMICS DISCUSSION PAPER. MIDDLEBURY COLLEGE.

Committee_on_University_Priorities. (1973). Report of the Committe on University Priorities.

Cunneen, K. M. ( 2003a, January 29). Minutes of the Meeting of the College Council.

Cunneen, K. M. ( 2003b, February 14). Minutes of the Meeting of the Dean's Advisory Committe (DAC).

CUP. (1973). Report of the Committe on University Priorities.

Delmas, M. A., \& Toffel, M. W. (2008). Organizational responses to environmental demands: Opening the black box. Strategic Management Journal, 29(10), 1027-1055.

ECOE. (2003). Strategic Plan for the Department of Economics.

Economics_Department. (1997). Self Study Report.

ECOP. (2003). A Strategic Plan for the New Department of Economics and Policy Studies

ECOP. (2010, January 29). Letter to College Council, Faculty Senate, and Academic Council against the proposal to close the department.

Faculty_Senate. (2010, February 01). Faculty Senate Statement on the Role of Departmental Affiliation in Tenure and its Application to the Proposed Reconfiguration of Economics at Notre Dame.

Fiol, C. M., Pratt, M. G., \& O'Connor, E. J. (2009). Managing Intractable Identity Conflicts. Academy of Management Review, 34(1), 32-55.

Gioia, D. A., Thomas, J. B., Clark, S. M., \& Chittipeddi, K. (1994). Symbolism and Strategic Change in Academia: The Dynamics of Sensemaking and Influence. Organization Science, 5(3), 363-383.

Greenwood, R., \& Suddaby, R. (2006). Institutional Entrepreneurship in Mature Fields: The Big Accounting Firms. Academy of Management Journal, 49(1), 27-48.

Kimberly, J. R., \& Bouchikhi, H. (1995). The Dynamics of Organizational Development and Change: How the Past Shapes the Present and Constrains the Future. [Article]. Organization Science, 6(1), 9-18.

Kipping, M., Usdiken, B., \& Puig, N. (2004). Imitation, tension and hybridization: Multiple "Americanizations" of management education in Mediterranean Europe. Journal of Management Inquiry, 13(2), 98-108.

Kuhn, T. S. (1962). The Structure of Scientific Revolutions. Chicago: University of Chicago Press.

Lawson, T. (2013). What is this 'school' called neoclassical economics? Cambridge Journal of Economics, 37(5), 947-983. doi: $10.1093 /$ cje/bet027

Lee, F. S., Grijalva, T. C., \& Nowell, C. ( 2009). Ranking Economics Deapartments in a Contested Discipline. White paper.

McKay, R. B. (2001). Organizational responses to an environmental bill of rights. Organization Studies, 22(4), 625-658. 
Ocasio, W. (1997). Towards an attention-based view of the firm. Strategic Management Journal, 18, 187-206. doi: 10.1002/(sici)1097-0266(199707)18:1+<187::aid-smj936>3.3.co;2-b

Oliver, C. (1991). Strategic Responses to Institutional Processes. Academy of Management Review, 16(1), 145-179.

Paul II, J. (1990, August 15,). Apostolic Constitution of the Supreme Pontiff John Paul II on Catholic Universities.

Powell, W. W., \& Colyvas, J. A. (2008). Microfoundations of Institutional Theory. In R. Greenwood, C. Oliver, K. Sahlin \& R. Suddaby (Eds.), The Sage Handbook of Organizational Institutionalism. London: Sage Publications.

Powell, W. W., \& DiMaggio, P. (1983). The iron cage revisited: Institutional isomorphism and collective rationality in organizational fields. American sociological review, 48(2), 147-160.

Ramanath, R. (2009). Limits to Institutional Isomorphism: Examining Internal Processes in NGO-Government Interactions. Nonprofit and Voluntary Sector Quarterly, 38(1), 51-76.

Randel, A. E., Jaussi, K. S., \& Standifird, S. S. (2009). Organizational Responses to Negative Evaluation by External Stakeholders The Role of Organizational Identity Characteristics in Organizational Response Formulation. Business \& Society, 48(4), 438-466.

Rodrigues, S., \& Child, J. (2008). The Development of Corporate Identity: A Political Perspective. Journal of Management Studies 45(5).

Seligman, B. (1962). Main Currents In Modern Economics: Economic Thought since 1870. New York: The Free Press of Glencoe.

Strategic_Planning_Coordinating_Committee. (2003, August). Notre Dame 2010: Fulfilling the Promise; a Provisional Strategic Planning Document to be submitted by the President. 
Table 1

Interviews

\begin{tabular}{|c|c|c|c|}
\hline Pseudonym & Occupation & $\begin{array}{l}\text { Interview in } \\
2010\end{array}$ & Interview in 2011 \\
\hline James Fletcher & $\begin{array}{l}\text { Professor } \\
\text { Chair of the Department of Economics and } \\
\text { Econometrics }\end{array}$ & Yes & Yes \\
\hline Robert Young & $\begin{array}{l}\text { Associate Professor } \\
\text { Department of Economics and Econometrics }\end{array}$ & Yes & Yes \\
\hline Caroline McGrath & $\begin{array}{l}\text { Associate Professor } \\
\text { Chair of the Economics and Policy Studies } \\
\text { department }\end{array}$ & Yes & $\begin{array}{l}\text { Was not available for a } \\
\text { second interview and } \\
\text { did not send } \\
\text { comments on the draft }\end{array}$ \\
\hline Charles Binder & $\begin{array}{l}\text { Carl Koch Professor of Economics and the } \\
\text { History and Philosophy of Science } \\
\text { Department of Economics and Policy Studies }\end{array}$ & Yes & $\begin{array}{l}\text { Was not available for a } \\
\text { second interview and } \\
\text { did not send } \\
\text { comments on the draft }\end{array}$ \\
\hline Peter Wiseman & Professor of Economics & $\begin{array}{l}\text { Was not } \\
\text { solicited for } \\
\text { the first round } \\
\text { of interviews }\end{array}$ & $\begin{array}{l}\text { Yes and sent } \\
\text { comments on the draft } \\
\text { before the meeting }\end{array}$ \\
\hline Paul Hatch & $\begin{array}{l}\text { Professor of German Language and Literature } \\
\text { Former dean of the College of Humanities and } \\
\text { Social Sciences (1997-2008) }\end{array}$ & Yes & $\begin{array}{l}\text { Yes and sent } \\
\text { comments on the draft } \\
\text { before the second } \\
\text { meeting }\end{array}$ \\
\hline Christian Marx & Professor of Economics & $\begin{array}{l}\text { Was not } \\
\text { solicited for } \\
\text { the first round } \\
\text { of interviews }\end{array}$ & $\begin{array}{l}\text { Yes and sent } \\
\text { comments on the draft } \\
\text { before the second } \\
\text { meeting }\end{array}$ \\
\hline Stephen McGuire & $\begin{array}{l}\text { Professor of History } \\
\text { Dean of the College of Humanities and Social } \\
\text { Sciences (2009-) }\end{array}$ & Yes & Yes \\
\hline John Goodwill & $\begin{array}{l}\text { Emeritus Professor of Economics } \\
\text { Former Chair of the Department of Economics } \\
(1975-1984)\end{array}$ & Yes & $\begin{array}{l}\text { Yes and sent } \\
\text { comments on the draft } \\
\text { before the second } \\
\text { meeting }\end{array}$ \\
\hline Alan Putnam & Executive Vice President of the University & Yes & $\begin{array}{l}\text { No and sent comments } \\
\text { on the draft. }\end{array}$ \\
\hline Jay Smart & UHS alumnus, economics major & Yes & $\begin{array}{l}\text { Was not solicited for a } \\
\text { second interview }\end{array}$ \\
\hline Liam Wright & UHS senior, economics major & Yes & $\begin{array}{l}\text { Was not solicited for a } \\
\text { second interview }\end{array}$ \\
\hline
\end{tabular}




\section{Table 2}

\section{Internal documents}

- University strategic plans: 1973, 1982, 2003

- Strategic plan for the department of economics: 2002

- Strategic plan for the department of Economics and Econometrics: 2003

- Strategic plan for the Economics and Policy Studies department: 2003.

- Economics Department self-study: 1997

- Summary of the three year follow-up meeting for the department of economics: 2001

- Economics Department reviews: 1975, 1988, 1997

- Blue Ribbon Committee on Economics Department: 2002

- Minutes of committee meetings:

- College Council

- Faculty Senate

- Ad-hoc Committee on Economics

- Academic Council

- Annual Reports of the Deans of the College of Humanities and Social Sciences

- Faculty addresses by the Deans of the College of Humanities and Social Sciences

- Memorandum addressed by the Dean of the College of Humanities and Social Sciences to the department of economics: 2002.

- Memorandum addressed by the Dean of the College of Humanities and Social Sciences to the Academic Council regarding the split of economics in two departments: 2003.

- Notes and internal communications related to economics 
ESSEC Business School Avenue Bernard Hirsch BP 50105

95021 Cergy-Pontoise Cedex France

Tél. +33(0)134433000

$\mathrm{Fax}+33(0) 134433001$

www.essec.fr

\section{ESSEC Executive Education} CNIT BP 230

92053 Paris-La Défense France

Têl. + $33(0) 146924900$

Fax +33 (0)1 46924990

http://formation.essec.fi

ESSEC Business School

Singapore Campus

100 Victoria Street

National Library Building \# 13-02

Singapore 188064

essecasia@essec.fr

Tél. +6568849780

Fax +6568849781

www.essec.edu

Informations

Alison Bougi

+33 (0)134433358

bougi@essec.fr

www.essec.fr

research.center@essec.fr

ISSN 1291-9616 